\title{
PRAWA IMIGRANTÓW A WYSIEDLANIE ROMÓW WE FRANCJI I REAKCJA UNII EUROPEJSKIEJ
}

W spółcześnie prawa imigrantów stanowią jeden z glównych problemów w ustawodawstwie Unii Europejskiej. Imigracja jest zjawiskiem zarówno sprzyjającym państwom, jak i powodującym liczne konfrontacje i niezadowolenie społeczne. Wobec tego procesu stanęła również Francja. Nasilenie się procesów imigracyjnych spowodowało napływ Romów, czego skutkiem stały się liczne protesty obywateli państwa przyjmującego, a w konsekwencji deportacja Romów z Francji.

Tezą niniejszej pracy jest stwierdzenie, iż podstawowe prawa imigrantów oraz ich swobody zapewnione przez prawodawstwo unijne zostały złamane przy deportacji Romów z Francji do Butgarii i Rumunii, a Dyrektywa o swobodnym przepływie osób na terenie Unii Europejskiej nie została w pełni wdrożona w życie przez państwo francuskie. Postawiono następujące pytania badawcze:

1. Jak Unia Europejska definiuje prawa imigrantów?

2. Jak kształtuje się sytuacja Romów w świetle regulacji prawnych?

3. Jaki wpływ na relacje pomiędzy państwem francuskim a Unią Europejską wywarła deportacja Romów?

4. Czy nagłośnienie sprawy romskiej wpłynęło na kształtowanie się wizerunku społeczno-kulturowego i stereotypu Romów w Unii Europejskiej?

5. Jak reakcja Unii Europejskiej wpłynęła na ustawodawstwo francuskie?
Dr Wojciech STANKIEWICZ jest adiunktem w Instytucie Historii i Stosunków Międzynarodowych Uniwersytetu Warmińsko-Mazurskiego w Olsztynie. wmstankiewicz@wp.pl 


\section{Zadania Unii Europejskiej w kwestii imigrantów}

Liczba imigrantów w Unii Europejskiej uległa znacznemu wzrostowi ${ }^{1}$ w przeciągu ostatnich dziesięcioleci, skutkując głębokimi zmianami w społeczeństwach państw, które przyjmują imigrantów. Zarówno państwa, jak i Unia Europejska powinny zwracać szczególną uwage na rozwój strategii i instytucji, które byłyby w stanie podołać nowym zadanio². Państwa członkowskie Unii Europejskiej mają umiejętność tzw. „adaptacji kreatywnej", która pozwala na uzyskanie równowagi pomiędzy wewnętrznym środowiskiem społeczeństw, a środowiskiem międzynarodowym³.

Polityka Unii Europejskiej wobec procesów imigracyjnych jest szczególnie ważna, gdyż związana jest z licznymi zmianami, jakie zachodzą w politykach krajowych pod wpływem integracji europejskiej. Istnieje dwupoziomowe rozpatrzenie kwestii dotyczących regulacji imigracji. Pierwszy poziom opiera się na migracjach międzypaństwowych obywateli krajów członkowskich. Drugi natomiast na migracjach osób pochodzących z państw trzecich. Międzynarodowe migracje z krajów trzecich powodują podejmowanie wspólnych działań przez państwa członkowskie, mające na celu kontrolowanie ruchów migracyjnych obywateli tych państw. Migracje obywateli innych krajów uregulowano w traktacie EWG oraz traktacie Unii Europejskiej.

W Traktacie ustanawiającym Wspólnotę Europejską, wraz z poprawkami naniesionymi przez traktat amsterdamski, wyliczono tzw. dziedziny polityki, w jakich od 1 maja 2004 r. zostały podjęte decyzje wiążące ${ }^{5}$. Na mocy tego traktatu został określony zakres polityki azylowej, wizowej oraz imigracyjnej Unii Europejskiej. Polityka azylowa jest polityką, która wyznacza kryteria, a także mechanizmy omawiające zasady, na podstawie których państwo członkowskie rozpatruje wniosek o azyl złożony przez obywatela państwa trzeciego. Określone są również normy, które regulują przyjmowanie osób pragnących otrzymać azyl w Unii Europejskiej, normy określające tych ludzi jako uchodźców oraz normy mówiące o sposobie udzielenia lub odebrania statusu uchodźcy ${ }^{6}$. Polityka imigracyjna wiąże się także z polityką łączenia rodzin imigrantów, walką z nielegalną imigracją i nielegalnym pobytem. Działania, które są podejmowane w jej ramach, dotyczą integracji imigrantów, kontrolowania granic, a także strategii imigracji zarobkowej. Kolejną gałęzią polityki imigracyjnej jest polityka wizowa Unii Europejskiej, mająca na celu określenie, które państwa trzecie mają posiadać wizy podczas przekraczania granic państw członkowskich. Formułuje także warunki, na jakich wydawane są wizy oraz to, jaki ma być ich format ${ }^{7}$.

Unia Europejska, starając się zwalczać źródła imigracji, stosuje politykę, która zasięgiem wykracza znacznie poza jej granice. Dotyczy ona pomocy humanitarnej ludziom imigrującym do Unii Europejskiej, współdziałania z „państwami pochodzenia imigrantów” oraz niedopuszczenia do nasilenia się migracji. Wspólna polityka Unii Europejskiej wobec procesów imigracyjnych uznaje instytucje rozwiązujące problemy imigracyjne. Jej organi-

Patrz: komu

2 K. Nowaczek, Polityka Unii Europejskiej wobec procesów imigracyjnych, Wydawnictwo Adam Marszałek, Toruń 2004, s. 13.

3 Ibidem, s. 14.

4 Ibidem.

5 S. Hambura, M. Muszyński, Traktat ustanawiający Wspólnotę Europejską z komentarzem, Studio STO, Bielsko-Biała 2002, s. 269-280.

6 Ibidem, s. 272-273.

7 K. Nowaczek, op. cit., s. 16. 
zacyjny wymiar określa wprowadzenie elementów i procedur ponadnarodowych do międzyrządowej współpracy, a także stworzenie systemów wymiany informacji (SIS)8 ${ }^{8}$, współdziałania policji (Europol), czy tworzenia bazy odcisków palców (Eurodac). Negatywnym aspektem tej polityki jest swobodny przepływ osób, który spowodował utworzenie regulacji dotyczących migracji obywateli państw trzecich. Istniejąca w ramach polityki międzyrządowa współpraca traktowana jest jako instrument walki z uchodźcami oraz nielegalnymi imigrantami. Zarządzenie uznano jednak jako przeszkodę w wyznawaniu liberalnych tradycji przez państwa Europy Zachodniej, które zostały wprowadzone zgodnie z zasadą integracji europejskiej9.

\section{Imigranci w ustawodawstwie europejskim}

Wszystkie kraje Unii Europejskiej realizują wspólną politykę imigracyjną. Kwestie związane z imigracją stały się dziedziną, którą zajmują się instytucje unijne - Komisja Europejska oraz Rada Europejska. Założeniami polityki imigracyjnej są: regulacje napływu imigrantów (z uwzględnieniem aspektu ekonomicznego i humanitarnego); właściwe traktowanie osób napływających do Unii Europejskiej z państw trzecich, mające wzgląd na prawo; rozwój partnerstwa i współdziałanie z krajami pochodzenia imigrantów, a także wspólna polityka azylowa ${ }^{10}$.

Prawodawstwo Unii Europejskiej dotyczące polityki imigracyjnej jest określane jako "wielopoziomowe”. Pierwszy obejmuje wymiar państwowy oraz europejski. Rywalizują one na płaszczyźnie podejmowania decyzji dotyczących treści polityki wobec procesów imigracyjnych. Drugi poziom stanowi wymiar wspólnotowy o restrykcyjnym charakterze, który dotyczy państw członkowskich lub prawa międzynarodowego, określający sterowanie procesami migracyjnymi oraz nadzór sądowy i respektowanie norm humanitarnych ${ }^{11}$.

Wraz z wejściem w życie traktatu amsterdamskiego podstawą prawną w Unii Europejskiej stał się tytuł IV Traktatu ustanawiającego Wspólnotę Europejską, który dotyczył azylu, imigracji, wiz, a także przepływu osób. Traktat nicejski z 2001 r. nie przyniósł w wielu aspektach żadnych zmian. Postanowienia traktatu amsterdamskiego utworzyły więc ramy prawne imigracyjnej polityki europejskiej, które mają funkcjonować jako przepisy pierwotnego prawa wspólnotowego. Podstawą planowania europejskiego stało się ustanowienie obszaru bezpieczeństwa, wolności i sprawiedliwości. Postanowienia traktatu ustanawiającego Konstytucję dla Europy z października 2004 r. zostały odrzucone przez państwa członkowskie, jednakże nie spowodowały przeszkody w realizacji i rozwoju wspólnotowego prawa imigracyjnego. Barierą stała się niezgoda między państwami dotycząca zasad przyjmowania imigrantów do Unii Europejskiej ${ }^{12}$.

W 2004 r. został przedstawiony tzw. Program haski, który zatwierdziła Rada Europejska. Jest on drugim wieloletnim programem, który ustanawia obszar wolności, bezpieczeństwa i sprawiedliwości. Wyznaczył on koniec wdrażania postanowień traktatowych, które miały na względzie obywateli państw trzecich oraz eliminację trudności występujących we współ-

8 System Informacyjny Schengen (ang. Schengen Information System) - komputerowa baza danych, pozwalająca ustalić, czy osoby lub przedmioty przekraczające granicę Strefy Schengen bądź już znajdujące się na jej terenie, nie są poszukiwane, niejawnie nadzorowane lub czy nie dotyczy ich zakaz wstępu.

9 K. Nowaczek, op. cit., s. 17-25.

10 P. Chmielewski, Unijne regulacje imigracyjne, http://www.psz.pl/tekst-2120/Unijne-regulacje-imigracyjne (data pobrania: 1.12.2010).

11 K. Nowaczek, op. cit., s. 25

12 I. Wróbel, Wspólnotowe prawo imigracyjne, Wydawnictwo Wolters Kluwer Business, Warszawa 2008, s. 37. 
pracy instytucji z państwami. Program haski ${ }^{13}$ dotyczył migracji na każdej płaszczyźnie. Przyznano na nim, iż legalna migracja będzie odgrywać znaczącą rolę W „umocnieniu gospodarki opartej na wiedzy, w dalszym rozwoju gospodarczym Europy, przyczyniając się tym samym do wprowadzenia w życie Strategii lizbońskiej"14. W Programie haskim zapewniono możliwość określenia liczby przyjmowanych imigrantów przez państwa członkowskie.

Komisja Europejska przedstawiła wyniki ogólnoeuropejskiej debaty, która była zainicjowana Zieloną Księgą ${ }^{15}$, skłaniającą do reagowania na zmiany popytu na pracę imigrantów na europejskim rynku pracy. Korzystne strony tego zjawiska przedstawiła Rada Europejska, twierdząc, iż pomyślna integracja obywateli państw trzecich oraz ich potomków legalnie zamieszkujących kraje unijne wpływa pozytywnie na spójność oraz stabilność przyjmujących społeczeństw.

Nielegalna imigracja zajęła również znaczące miejsce w tym programie. Wspieraniem państw nieradzących sobie z kontrolą i nadzorem długich i uciążliwych odcinków granic, gdzie występuje znaczne natężenie migracji, miały zajmować się zespoły złożone z ekspertów krajowych, zapewniające pomoc techniczną, jak i operacyjną. Rada i Komisja W czerwcu 2005 r. ratyfikowały plan realizacji Programu haskiego ${ }^{16}$.

W 2006 r. Parlament Europejski zatwierdził rezolucję w sprawie wspólnej polityki imigracyjnej Unii Europejskiej. Zaproponowano w niej stworzenie tzw. funduszu kryzysowego, który miałby finansować pomoc w przyjmowaniu migrantów oraz problemów związanych z kryzysami humanitarnymi. Rezolucja stała się częścią polityki imigracyjnej Unii Europejskiej oraz europejskiego systemu azylowego, stanowiąc podział odpowiedzialności między państwa członkowskie ${ }^{17}$.

16 października 2008 r. w Brukseli uchwalono Pakt europejski o imigracji i udzielaniu azylu. Ustanowiono w nim, iż rządy państw członkowskich mają na celu współpracę w zakresie imigracji zarobkowej, udzielania azylu oraz deportacji, a „od połowy 2010 roku Unia Europejska będzie odbywała co roku debatę na ten temat"18.

\section{Uzyskanie azylu w Unii Europejskiej}

Sama definicja azylu pełna jest kontrowersji natury prawnej i politycznej. Potrzebę reform przyspiesza stały wzrost liczby osób, które ubiegają się o azyl na terytorium Unii Europejskiej, a także unijne przepisy, które pozwalają państwom członkowskim na kształtowanie własnych decyzji i kryteriów, według których przyznają azy ${ }^{19}$. Jeżeli niektóre państwa wprowadziłyby zasady bardziej restrykcyjne niż pozostałe, uchodźcy próbowaliby przedostać się do Unii Europejskiej przez te kraje, w których uzyskanie azylu ma największe szanse powodzenia. To doprowadziłoby do powstania niesprawiedliwego braku równowagi ${ }^{20}$.

13 Program Haski: Wzmacnianie wolności, bezpieczeństwa i sprawiedliwości w Unii Europejskiej (2005/c 53/01), Dz. U. Unii Europejskiej, C 53/1.

14 Plan rozwoju przyjęty dla Unii Europejskiej przez Radę Europejską na posiedzeniu w Lizbonie 23 i 24.03 .2000 r.

15 Celem tego dokumentu było otwarcie debaty o bezpieczeństwie energetycznym, które zostało uznane za najważniejszy element niezależności polityczno-ekonomicznej UE.

16 I. Wróbel, op. cit., s. 40-44.

17 Wspólna polityka imigracyjna, http://www.europolityka.pl/kul/imigracja.html (data pobrania: 1.12.2010).

18 R. Kowalczyk, Nowy pakt o migracji nada kierunek polityce imigracyjnej Unii Europejskiej, http://www.euranet.eu/pol/Raporty/Imigracja-legalna/Nowy-pakt-o-migracji-nada-kierunek-polityce-imigracyjnej-Unii-Europejskiej (data pobrania: 1.12.2010).

19 Wspólnotowy azyl, http://www.twojaeuropa.pl/34/wspolnotowy-azyl (data pobrania: 3.12.2010).

20 EURODAC, Baza danych odcisków palców pomocna w procedurze przyznawania azylu, Dyrekcja Generalna ds. SPRAWIEDLIWOŚCI, WOLNOŚCI I BEZPIECZENSTWA, Komisja Europejska, Bruksela 2004, http:// ec.europa.eu/justice_home/key_issues/eurodac/eurodac_20_09_04_pl.pdf (data pobrania: 27.12.2009). 
Rozumienie pojęcia „azyl” wynika z definicji omawianego pojęcia. Janusz Balicki i Peter Stalker wyjaśniają pojęcie azylu jako synonim "statusu uchodźcy”, czyli "instytucji prawnej opartej na Konwencji Genewskiej z 1951 r. dotyczącej uchodźców"21. Marek Okólski uważa natomiast, że pojęcie azylu odnosi się do prześladowań cudzoziemców w krajach przyjmujących. Osoby takie mogą uzyskać status zbliżony do statusu uchodźcy lub z nim identyczny. „Przyznawanie azylu nie jest jednak regulowane przepisami prawa międzynarodowego, lecz przez specyficzne rozwiązania przyjęte przez poszczególne państwa, ma więc w pewnym sensie charakter wyznaniowy" ${ }^{22}$. Według Poradnika dla ubiegających się o azyl osoba, która ubiega się o azyl, „musi wykazać, że jest narażona na ryzyko prześladowań z uwagi na rasę, wyznanie, narodowość, przekonania polityczne lub przynależność do określonej grupy społecznej oraz że rząd jej kraju nie może lub nie chce zapewnić jej ochrony"23.

Z pojęciem azylu wiąże się pojęcie uchodźcy. Izabela Wróbel określa uchodźców jako emigrantów przymusowych, którzy opuszczają swój kraj z obawy przed prześladowaniem, która jest uzasadniona ${ }^{24}$.

Jednym z warunków uzyskania azylu jest prześladowanie jednostki lub grupy w kraju ojczystym, przede wszystkim prześladowanie o charakterze politycznym. Odmowa nadania prawa azylu zachodzi wówczas, gdy państwo członkowskie nie uzna, iż okoliczności prześladowania są wystarczające. Ponadto, „rzeczywiste zaistnienie owego prześladowania i tak nie przesądza o przyznaniu prawa do azylu". Często państwo nie przyznaje azylu, gdyż powoduje konflikt o podłożu międzynarodowym z państwem, z którego pochodzi dana osoba, lub państwo nie życzy sobie mieć źle wykształconych, nieznających języka imigrantów ${ }^{25}$

\section{SYTUACJA ROMÓW W ŚWIETLE REGULACJI PRAWNYCH I UWARUNKOWAŃ SPOLECZNYCH}

Migracje i Romowie w liczbach

Dla większości Romów migracyjny tryb życia stanowi taktykę przetrwania. W ostatnim dwudziestoleciu przemieszczanie się tej grupy etnicznej na Zachód spowodowane było głównie przyczynami ekonomicznymi, społecznymi i politycznymi takimi, jak nienawiść, przemoc czy uprzedzenia etniczne. Koczownictwo stało się główną strategią życia rodzin romskich, przeważnie w krajach Europy Zachodniej. Jednak w ostatnich latach rodziny te ulegają przestrzennej stabilizacji, żyjąc w przeznaczonych dla nich miejscach postojowych (caravan sites). Migrujący Romowie poszukują lepszych warunków życia, uciekając przed zagrożeniami. Paradoksalnie jednak stają się obiektem przemocy w Europie Zachodniej ${ }^{26}$.

\section{-....}

21 J. Balicki, P. Stalker, Polityka imigracyjna i azylowa, Wydawnictwo Uniwersytetu Kardynała Stefana Wyszyńskiego, Warszawa 2006, s. 21.

22 M. Okólski, Demografia. Podstawowe pojęcia, procesy i teorie w encyklopedycznym zarysie, SCHOLAR, Warszawa 2004, s. 175-176.

23 Poradnik dla ubiegających się o azyl, Londyn 2007, http://www.lawsociety.org.uk/documents/downloads/ asylum_polish.pdf (data pobrania: 12.11.2009).

24 I. Wróbel, op. cit., s. 56.

25 Wspólnotowy azyl, http://www.twojaeuropa.pl/34/wspolnotowy-azyl (data pobrania: 3.12.2010).

26 A. Mirga, N. Gheorghe, Romowie w XXI wieku. Studium polityczne, Universitas, Kraków 1998, s. 50-52. 
Społeczności romskie żądają uznania jako mniejszości „europejskiej” i „ponadnarodowej". Problem romski wówczas wydaje się problemem o wymiarze europejskim, potrzebującym rozpatrzenia w kontekście międzynarodowym. Zwolennicy tego zdania grupują się spośród uchodźców, azylantów, migrantów i bezpaństwowców. Przywódcy tych grup, zdając sobie sprawę z licznych nierówności i ograniczeń, które są wynikiem obecnie stosowanych praw mniejszości, żądają ochrony ze strony prawa krajowego i międzynarodowego. Antagonizmy wynikające z tych żądań odzwierciedlają mechanizmy społecznych i politycznych realiów we współczesnych systemach politycznych i międzynarodowych ${ }^{27}$.

Romowie w Europie są rozproszoną, dużą zbiorowością. Jej liczebność określana jest w granicach 6-12 mln. Najliczniej ta grupa etniczna występuje w Europie Południowej, Wschodniej i Centralnej. Ostatnie lata pokazały, iż ta społeczność stała się przedmiotem zainteresowania, ponieważ gwałtowne zmiany społeczne doprowadziły do pogorszenia ich niekorzystnego położenia i pogłębienia dyskryminacji28. Po przyjęciu do Unii Europejskiej w 2007 r. Bułgarii i Rumunii wzmocnieniu uległy konflikty i przejawy agresji na tle etnicznym wobec Romów, które spowodowane były otwarciem granic na inne kraje unijne i możliwością swobodnego przemieszczania się. Dla rządów poszczególnych krajów stało się oczywiste, iż do marginalizowania grup romskich doszło nie tylko z własnego wyboru Romów, ale również z winy otoczenia, w którym żyją ${ }^{29}$.

We Francji Romów określa się mianem „nomadów”, czyli ludzi wędrownych, którzy nie posiadają stałego miejsca zamieszkania. Status ten określono prawnie w 1970 r. Romowie pochodzaccy z Bułgarii i Rumunii nie zostali zakwalifikowani do tej kategorii. Liczba Romów zamieszkujących Francję wynosi 350-400 tys. ${ }^{30}$ Około 12 tys. Romów przebywa we Francji nielegalnie ${ }^{31}$.

\section{Status mniejszości romskiej}

Naród jest dla Romów pewną wartością symboliczną, polityczną i moralną, nie stanowiąc kategorii prawnej. Grupa ta funkcjonuje w większości państw na zasadzie widocznych mniejszości. Romowie chcą być traktowani jako obywatele korzystający z podstawowych wolności i praw, czy jako mniejszość, która posiada prawo do ochrony i korzystania z przywilejów przysługującym mniejszościom. Elity romskie utrzymują żądania uznania ich za mniejszość.

Romowie podejmują różne stanowiska dotyczące pojęcia mniejszościowego statusu Romów. Jednym z najmniej rozpowszechnionych zdań jest stawianie kwestii romskiej w ramach powszechnych praw człowieka i społeczeństwa obywatelskiego. Odrzucone zostają wówczas żądania przyznania Romom statusu mniejszości, ponieważ taka postawa doprowadziłaby do wzmocnienia społeczeństwa obywatelskiego oraz zakładałaby istnienie instytucji o podłożu liberalnym i przestrzeganie zasad równości. Swoboda tożsamości narodowej czy etnicznej, swoboda wyznania religijnego i orientacji politycznej stanowiłyby cechy tego społeczeństwa.

Przeświadczenie o „etnicznym nacjonalizmie” i rosnącej świadomości etnopolitycznej zdecydowanie dominuje wśród przywódców romskich. Podniesienie grupowego statusu

\section{......}

27 Ibidem, s. 53

28 Ibidem, s. 9.

29 L. Mróz, Od Cyganów do Romów. Z Indii do Unii Europejskiej, Wydawnictwo DiG, Warszawa 2007, s. 224-225.

30 Romowie dyskryminowani we Francji, Polska Agencja Prasowa, http://www.tvp.info/informacje/swiat/romowie-dyskryminowani-we-francji/2243268 (data pobrania: 3.12.2010).

31 M. Ostrowski, Francja wydala Romów. Potepiajmy, ale bez hipokryzii, http://www.polityka.pl/swiat/ komentarze/1508600,1,francja-wydala-romow.read (data pobrania 4.12.2010). 
Romów oraz ich osobistej godności spowoduje uznanie ich narodowej czy etnicznej tożsamości, rozwiązując liczne problemy, przed którymi stoi romska społeczność. Po pierwsze, zakładane jest wezwanie do uzyskania takiej samej ochrony i praw, które gwarantowane są przez ustawy innym mniejszościom w danym państwie. Po drugie, mniejszość romską określono jako wyjątek, nie tylko ze względu na porównanie ich z innymi mniejszościami, ale przede wszystkim na ich szczególną sytuację ${ }^{32}$.

Narodowy Kongres Romów ${ }^{33}$ wykazuje natomiast, iż Romowie są prawowitym narodem Europy, jednym z wielu, który ze względów historycznych i politycznych zajmuje pośród nich szczególne miejsce. Romowie pozostają narodem bez państwa i bez terytorium, a z powodu doświadczenia licznych prześladowań i rasizmu powinni być narodem specjalnie chronionym. Narodowy Kongres Romów zaproponował utworzenie „Europejskiej Karty Praw Romów", która miałaby być zatwierdzona przez państwa europejskie. Organizacja utrzymuje również, że polityka tradycyjna nie spełniła swojego zadania w jednoczeniu się Europy, a standardy prawne w odniesieniu do Romów uległy pogorszeniu.

Międzynarodowa Unia Romów ${ }^{34}$ twierdzi, iż „naród Romów” prawomocnie wpisuje się W dziedzictwo europejskiej kultury i społeczeństwa. Z punktu widzenia swojej wyjątkowości historycznej zasługuje na traktowanie w specjalny sposób. Organizacja opowiada się za uznaniem romskiej społeczności za naród i przyznania Romom specjalnego statusu „mniejszości nieterytorialnej”, czyli rozproszonej w wielu państwach Europy, po to aby zapewnić im ochronę $e^{35}$.

Przyznanie Romom statusu mniejszości ponadnarodowej i bezterytorialnej doprowadziłoby do uniknięcia mylnego postrzegania praw człowieka i praw kulturalnych, które mogłyby wiązać się z roszczeniami terytorialnymi. Takie podejście stanowi swoisty krok naprzód ku uznaniu społeczności romskiej za mniejszość narodową. Pogłębia jednak podziały w społeczności romskiej w danym kraju, gdyż prawne korzyści nadane przez ustawę o mniejszości obejmują niekiedy tylko członków społeczności romskiej z obywatelstwem danego kraju, a nie uwzględniają osób migrujących i rezydentów ${ }^{36}$.

Uzyskanie praw mniejszości narodowej ma duże znaczenie dla społeczności romskiej, gdyż zrównuje ich pozycję z innymi społecznościami narodowymi bądź etnicznymi w danym państwie. Niektóre organizacje Romów w Europie żądają uznania Romów za mniejszość, która przekracza własne, wewnętrzne różnice kulturowe, a także granice państwowe. Powoduje to jednak narastające problemy prawne i polityczne, które nie są zgodne z koncepcją ochrony mniejszości etnicznych i narodowych w Europie. Podejście to sprawia, iż pojawia się pytanie o kwestię ochrony praw gwarantowanych przez rządy poszczególnych krajów i lojalności obywatelskiej37.

Prawny i polityczny status Romów

W dokumentach międzynarodowych określono Romów jako podmiot chroniony przez prawo. Istnieje szereg określeń dotyczących romskiej społeczności, a wśród nich wyróżnia się: "nomadów”, "migrantów”, „uchodźców”, "mniejszość narodową” lub „etniczną”,

\section{......}

A. Mirga, N. Gheorghe, op. cit., s. 41-44.

Organizacja Romów w Niemczech.

Organizacja powstała w 1973 r., reprezentująca interesy Romów z całego świata.

A. Mirga, N. Gheorghe, op. cit., s. 47-48.

36 Ibidem, s. 53.

37 S. Łodziński, Romowie - bliscy i dalecy, http://free.art.pl/podkowa.magazyn/nr3132/romowie.htm (data pobrania: 5.12.2010). 
„mniejszość ponadnarodową" i "mniejszość transeuropejską". Określenia te sprawiają wyraźne trudności w ujęciu tej unikatowej tożsamości społeczności romskiej występującej w terminach prawnych i politycznych. Przedmiot ochrony Romów mógłby zaistnieć publicznie jedynie wtedy, gdy zaistniałoby świadectwo dociekania specjalnej przestrzeni politycznej i języka prawnego. Zróżnicowanie ze względu na posiadanie prawnego statusu społeczności romskiej oraz jej wielokulturowy aspekt stanowią wyzwanie dla podstawowego zrozumienia pojęcia mniejszości międzynarodowej. Nie jest to jedna spójna mniejszość z własną kulturą, ale różnorodna społeczność o odmiennej kulturze, dystansująca się od otoczenia, posiadająca zróżnicowany status prawny. Dylematy w uznaniu Romów z jednej strony za mniejszość ponadnarodową, a drugiej za narodową prowadzą do ważnych skutków politycznych i praktycznych ${ }^{38}$.

W 2000 r. Rada Europy otworzyła do podpisu nowy Protokół 12 do Europejskiej Konwencji Praw Człowieka. W efekcie, po uprzednim ratyfikowaniu przez 10 państw członkowskich, w Protokole 12 zapewniono powszechny zakaz dyskryminacji w ramach wykonywania prawa. W dokumencie tym znacznie rozszerzono zabezpieczenia osób $w$ ramach Europejskiej Konwencji Praw Człowieka. Chroni on więc Romów pod względem społecznym i gospodarczym, ale także prawnym i politycznym. Ponadto istnieje wiele inicjatyw politycznych dotyczących Romów, podjętych obecnie przez organizacje międzynarodowe, do których zalicza się: Radę Europy, OBWE, Program Narodów Zjednoczonych ds. Rozwoju (UNDP - United Nations Development Programme) i Bank Światowy. Przykładem inicjatywy prawnomiędzynarodowej jest projekt „Roma under the Stability Pact". Jest on finansowany w ramach Europejskiej Inicjatywy na rzecz Praw Człowieka we współpracy z OBWE i Radą Europy. Pomimo ograniczonego zakresu inicjatywa ta osiągnęła znaczne sukcesy. Doprowadziła ona m.in. do uwidocznienia kwestii romskiej na arenie międzynarodowej, zwiększenia współpracy dotyczącej polityki spójności oraz poprawy sytuacji Romów na poziomie europejskim ${ }^{39}$.

Romowie są jednak słabo reprezentowani $w$ instytucjach politycznych. W lutym 2010 r. w Raporcie Rady Europy wskazano, iż należy podjąć wszelkie działania dla zwiększenia uczestnictwa i reprezentacji Romów w życiu publicznym i politycznym, w szczególności w ramach Zgromadzenia Parlamentarnego ${ }^{40}$.

\section{DEPORTACJA ROMÓW Z FRANCJI}

\section{Przyczyny deportacji Romów}

Sytuacja we Francji w sierpniu 2010 r. była efektem wydarzeń z 18 lipca 2010 r. w okolicach miasteczka Saint-Aignan. Romowie, atakując miejscowy posterunek żandarmerii, chcieli zaprotestować przeciwko agresji wobec ich społeczności. Ponadto około 50 przedstawicieli społeczności romskiej, uzbrojonych w metalowe pręty i siekiery, dopro-

38 Ibidem

39 The Situation of Roma in an Enlarged European Union, European Commissions. Directorate-General for Employment and Social Affairs Unit D3, Manuscript completed in 2004, Luxembourg: Office for Official Publications of the European Communities, 2004, s. 16, http://www.errc.org/cms/upload/media/00/E0/ m000000E0.pdf (data pobrania 6.12.2010).

40 The situation of Roma in Europe and relevant activities of the Council of Europe, Report Committee on Legal Affairs and Human Rights, Doc. 12174, Strasbourg 2010, s. 1 http://assembly.coe.int/Documents/WorkingDocs/Doc10/EDOC12174.pdf (data pobrania: 6.12.2010). 
wadzito do wielu zniszczeń, m.in. dewastacji rosnących w pobliżu posterunku drzew, spalenia 3 samochodów i zniszczenia sygnalizacji świetlnej. Atak ze strony Romów spowodowany był zastrzeleniem przez żandarmów francuskich młodego Roma, Luigiego Duqueneta, uciekającego przed policją, który po długim pościgu chciał staranować zaporę ustawioną przez funkcjonariuszy ${ }^{41}$. Ciało Roma zostało porzucone w pobliżu dużego obozu romskiego.

28 lipca 2010 r. prezydent Francji Nicolas Sarkozy zorganizował spotkanie ministrów spraw wewnętrznych, sprawiedliwości i ds. imigracji, a także wysokich rangą funkcjonariuszy francuskiej policji. Podczas spotkania omawiano "kwestie zachowania niektórych" Romów w czasie zamieszek ${ }^{42}$. Sarkozy zapowiedział wówczas, iż do końca października zostanie zlikwidowana połowa z około 300 romskich obozowisk i "squatów" 43 we Francji. Złożoną pod koniec lipca deklarację $w$ tej sprawie postanowiono wdrożyć w życie. Taktyka ta była tłumaczona "działaniami w sferze bezpieczeństwa", a także walką z wykorzystywaniem dzieci, handlem ludźmi i prostytucją ${ }^{44}$.

30 lipca 2010 r. w Grenoble prezydent Francji wygłosił przemówienie, w którym przedstawił sposoby zachowania określonych środków bezpieczeństwa. Wśród nich wyróżniono: pozbawienie obywatelstwa naturalizowanych imigrantów, którzy atakują policjantów i żandarmów, zaostrzenia w przyznawaniu statusu obywatela oraz instalację około 60 tys. kamer nadzoru w miejscach publicznych ${ }^{45}$. Sarokozy ogłosił również zamknięcie setek nielegalnych obozów romskich, zamieszkanych przez Romów z Bułgarii i Rumunii, a także ich wydalenie do krajów pochodzenia ${ }^{46}$.

Pierwszym nielegalnym obozem Romów, który został zlikwidowany po wydaniu deklaracji, był obóz w Saint-Etienne w środkowej Francji. O tym wydarzeniu poinformowała międzynarodowa organizacja Sieć Solidarności z Romami („Commission de Solidarité” of the Rome Group). Decyzje o likwidacji siedlisk romskich władze tłumaczyły brakiem prawnego pozwolenia na obozowiska. 30 lipca 2010 r. rodziny romskie zostały usunięte $z$ nielegalnie zajmowanego przez nie domu w Montreuil w regionie paryskim, skąd wyrzucono około 50 osób, w tym dzieci. Prezydent Sarkozy wyjaśnił wówczas, iż obozowiska Romów "będą systematycznie ewakuowane"47. Tego samego dnia pojawiło się wiele głosów krytykujących Unię Europejską. Amnesty International uznała, iż Unia Europejska powinna stosować odpowiednie sankcje dla krajów, które łamią prawa człowieka w odniesieniu do Romów. Jednym z surowszych środków, które powinny być zastosowane, jest pozbawienie prawa do głosowania i w konsekwencji wykluczenie z Unii, w myśl postanowień Karty Praw Podstawowych, która weszła w życie w 2009 r. wraz z Traktatem lizbońskim. Brak reakcji ze strony unijnej potraktowano jako nieprzestrzeganie Karty ${ }^{48}$.

\footnotetext{
41 G. Dobiecki, Zty policjant Sarokozy, "Wprost”, nr 31/2010, s. 70.

42 Romowie dyskryminowani we Francji, Polska Agencja Prasowa, http://www.tvp.info/informacje/swiat/romowie-dyskryminowani-we-francji/2243268 (data pobrania: 7.12.2010).

43 Opuszczone pomieszczenie lub budynek, zajęty przeważnie bez zgody prawowitego właściciela.

44 M. Hawranek, Sarkozy chce zlikwidować romskie siedliska, http://wolnemedia.net/wiadomosci-ze-swiata/ sarkozy-chce-zlikwidowac-romskie-siedliska/ (data pobrania 3.12.2010).

45 Sarko zawinit, Cygana powiesili, http://www.polityka.pl/swiat/tygodnikforum/1508322,1,francja-dla-francuzow.read?backTo=http://www.polityka.pl/swiat/komentarze/1508600,1,francja-wydala-romow.read (data pobrania: 6.12.2010)

46 C. Dickey, Sarkozy's Right-Wing Rubicon, "Newsweek”, August 17, 2010, s. 64

47 Francja: policja zlikwidowała obóz Romów, Polska Agencja Prasowa, http://tvp.info/informacje/swiat/francjapolicja-zlikwidowala-oboz-romow/2325717.

48 J. Klebaniuk, Unia Europejska przymyka oczy na dyskryminację Romów, http://www.lewica.pl/?id=22107 (data pobrania: 3.12.2010)
} 


\section{Pierwsze deportacje}

19 sierpnia 2010 r. rozpoczęto pierwsze deportacje bułgarskich i rumuńskich Romów. Mimo krytyki na całym świecie Francuzi w większości popierali zaostrzoną politykę imigracyjną. Ustalono, iż około 700 osób pochodzenia romskiego zostanie wydalonych z Francji w najbliższych dniach. Pierwszego dnia deportacji z lotniska w Lyonie odleciało 75 osób. Zapowiedziano wówczas także, że wysiedlenia te będą trwały do końca września. 20 sierpnia 2010 r. w brytyjskim dzienniku "The Independent" napisano: "Wątła kondycja globalnej gospodarki nie może być usprawiedliwieniem dla antyimigracyjnej ksenofobii widocznej w różnych państwach świata. Nie powinni jej ulegać zwłaszcza politycy. Imigranci często są kozłami ofiarnymi, zwłaszcza w okresie gospodarczego stresu. Francja (...) nie jest żadnym wyjątkiem"49. Gazeta przytaczała ponadto opinie krytyków, którzy twierdzili, że wydalanie Romów jest próbą odwrócenia uwagi od skandali w rządzie prezydenta Nicolas'a Sarkozy'ego ${ }^{50}$.

Kolejne deportacje Romów zaplanowano na 26 sierpnia i we wrześniu 2010 r. Ministerstwo Spraw Wewnętrznych zapewniło opinię publiczną, że społeczność romska zostanie przewieziona do Bułgarii i Rumunii lotami międzypaństwowymi. Osoby, które nie miały uregulowanego prawnie pobytu w państwie francuskim, uzyskały refundacje na przeloty oraz pomoc finansową w wysokości 100 euro dla dzieci i 300 euro dla osób dorosłych. Francuski rząd zapowiedział, iż Romowie zostaną wydaleni z Francji w przeciągu 3 miesięcy, a zaostrzenie przepisów imigracyjnych ma zapobiec napływowi nielegalnych imigrantów. Sytuacja doprowadziła do ochłodzenia stosunków dyplomatycznych na linii Paryż-Bukareszt. Minister spraw zagranicznych Rumunii Teodor Baconschi uznat, iż decyzje Francji stanowią wyraz ksenofobii. Ponadto, prezydent Rumunii Traian Basescu oznajmit, iż wydarzenia we Francji nasuwają potrzebę opracowania europejskiego programu integracji Romów ${ }^{51}$.

31 sierpnia 2010 r. francuski rząd wyjaśnit, iż wszelkie działania podejmowane przeciwko Romom są zgodne z prawem Unii Europejskiej. Minister ds. imigracji Eric Besson oświadczył, iż Francja została potraktowana w sposób nie do zaakceptowania. Unijna komisarz ds. sprawiedliwości Viviane Reding wezwała państwo francuskie do poszanowania w pełni przepisów Unii Europejskiej o swobodzie przemieszczania się i osiedlania obywateli Unii oraz oznajmiła, iż społeczeństwo romskie „ma takie same prawa jak inni obywatele Unii, integracja zaś dotyczy całej Europy". Ponadto ustalono, iż sprawa romska stanie się przedmiotem sesji Parlamentu Europejskiego we wrześniu 2010 r. ${ }^{52}$

Organizacje obrony praw człowieka we Francji wniosły sprzeciw odnośnie do zaostrzenia polityki wobec społeczności romskiej, twierdząc, iż deportacje Romów nie są nowym zjawiskiem. Dodatkowo, Romowie posiadają paszporty Bułgarii i Rumunii, czyli mogą swobodnie poruszać się po Unii Europejskiej, a więc mają prawo do powrotu do Francji. Zgodnie z prawem, społeczność romska może być usunięta z terenu Francji przed upływem 3 miesięcy pobytu, jedynie wtedy, jeśli dopuści się zakłócenia porządku publicznego lub stanie się ciężarem dla opieki społecznej53.

\section{-. •. •}

49 Romowie z Francji, obywatele UE z Włoch!, http://www.naszswiat.net/wiadomosci/755-romowie-z-francjiobywatele-ue-z-woch.html (data pobrania: 12.12.2010).

50 Ibidem.

51 A. Iwulski, Pierwsze deportacje Romów z Francji, http://polonia.wp.pl/title,Pierwsze-deportacje-Romow-zFrancji,wid, 12588022, wiadomosc.html?ticaid=1b6e5 (data pobrania: 12.12.2010).

52 Sprawa Romów: Francja się broni, http://www.wprost.pl/ar/207707/Sprawa-Romow-Francja-sie-broni/ (data pobrania: 13.12.2010)

53 Francuzi wyrzucają Romów ze swojego kraju, Polska Agencja Prasowa, http://wiadomosci.dziennik.pl/swiat/ artykuly/299338, francuzi-wyrzucaja-romow-ze-swojego-kraju.html (data pobrania: 14.12.2010). 
We Francji doszło do licznych manifestacji i strajków przeciwko polityce rządu. Uczestnicy manifestowali przeciw restrykcyjnym regulacjom dotyczącym imigrantów, których rząd wini za wzrost niebezpieczeństwa w państwie. Strajki odbywały się w Paryżu, Marsylii, Tuluzie i Bordeaux. Badania opinii publicznej we Francji wykazały, iż społeczeństwo w znacznej mierze popiera rozprawienie się z nielegalnymi obozami. Jeden z członków rządzącej partii (Unia na rzecz Ruchu Ludowego - Union pour un Mouvement Populaire) Sarkozy'ego porównał wysiedlenia Romów do łapanek francuskich Żydów w czasie II wojny światowej ${ }^{54}$.

Na początku września 2010 r. prezydent Sarcozy przedstawił ustawę o możliwości odebrania obywatelstwa, która była już 18. ustawą dotyczącą bezpieczeństwa (od 2002 r. $)^{55}$. Pomysł ten wzbudził znaczne kontrowersje. Zapowiedziano także wdrożenie przepisów, które miałyby uprościć deportację cudzoziemców, w przypadku zagrożenia dla porządku publicznego czy nadużywania swobody przemieszczania się. Kwestia wydalenia Romów nadal budziła największe emocje, a planowana na ten temat dyskusja w Parlamencie Europejskim miała rozstrzygnąć sytuację ${ }^{56}$.

9 września 2010 r. odbyło się spotkanie Parlamentu Europejskiego. PE zażądał wstrzymania deportacji społeczności romskiej z Francji. Stanął także w obronie prawa do ich osiedlania się na terytorium Unii Europejskiej oraz prawa do przemieszczania się. W ogłoszonej wówczas rezolucjij ${ }^{57}$ zawarto wezwanie właściwych organów do zatrzymania deportacji Romów ${ }^{58}$.

13 września 2010 r. Wysoka Komisarz ONZ ds. praw człowieka Navi Pillay, otwierając 15. sesję Rady Praw Człowieka ONZ w Genewie, wezwała państwa europejskie do przyjęcia polityki, która umożliwiłaby Romom walkę z zepchnięciem ich na margines społeczeństwa. Komisarz uznała, iż sytuacja we Francji jest dyskryminująca i oparta na stereotypach, co może pogłębić istniejące już ubóstwo Romów ${ }^{59}$.

14 września 2010 r. Komisja Europejska wystosowała jawną krytykę wobec Francji, twierdząc, iż hańbą jest likwidacja obozów Romów i porównując sytuację z II wojną światową. Do Bułgarii i Rumunii odesłano ponad 1000 Romów, a komisarz Reding zagroziła państwu francuskiemu pozwaniem do trybunału sprawiedliwości za łamanie prawa europejskiego. Rząd francuski jednak nie chciał wchodzić w polemikę ani z Parlamentem Europejskim, ani z Komisją Europejską ${ }^{60}$.

16 września 2010 r. Jerzy Buzek, szef Parlamentu Europejskiego, stwierdzit, iż problem Romów nie jest jedynie problemem Francji, ale całej Unii Europejskiej. Kwestia wydalenia

\section{$\cdots \cdots \cdot$}

54 Roma in France: Frequently asked questions, France 24, 15.09.2010, http://www.france24.com/ en/20100914-roma-france-frequently-asked-questions-travelling-people-romania-bulgaria-immigraiton-policy (data pobrania: 3.01.2011)

55 G. Dobiecki, Pót-Francuzi, "Wprost”, nr 33/2010, s. 61.

56 D. Pszczółkowska, Kogo Francja wyrzuci, http://wyborcza.pl/1,75477,8342980,Kogo_Francja_wyrzuci.html (data pobrania: 6.12.2010)

57 Patrz: Rezolucja Parlamentu Europejskiego z dnia 9 września 2010 r. w sprawie sytuacji Romów i swobody przemieszczania sie w Unii Europejskiej, http://www.europarl.europa.eu/sides/getDoc.do?pubRef=-//EP// TEXT+TA+P7-TA-2010-0312+0+DOC+XML+V0//PL (data pobrania: 3.12.2010).

58 PE: Natychmiast wstrzymać wydalenia Romów z Francji, Państwowa Agencja Prasowa, http://wiadomosci. gazeta.pl/Wiadomosci/1,80708,8354164,PE_Natychmiast_wstrzymac_wydalenia_Romow_z_Francji.html (data pobrania: 7.12.2010)

59 Komisarz ONZ: sytuacja Romów we Francji jest niepokojąca, Polska Agencja Prasowa, http://wiadomosci. onet.pl/swiat/komisarz-onz-sytuacja-romow-we-francji-jest-niepok,1,3659193, wiadomosc.html (data pobrania: 12.12.2010).

60 D. Pszczółkowska, Francja obrażona na Bruksele za Romów, http://wyborcza.pl/1,75477,8381070,Francja_ obrazona_na_Bruksele_za_Romow.html (data pobrania: 13.12.2010). 
społeczności romskiej stała się głównym medialnym tematem spotkania. Na szczycie Unii Europejskiej apelowano jednak o spokój w sprawie Romów wydalonych z Francji61.

29 września 2010 r. Navi Pillay oświadczyła, iż Europa wciąż traktuje Romów w negatywny sposób. Ponadto uznała, że jedynym pozytywnym aspektem tej sytuacji jest to, iż zjawisko dyskryminacji stało się centrum zainteresowania na całym świecie. Rozwiązanie problemu musi nastąpić we właściwy sposób, ponieważ doszło do wzrostu liczby manifestacji strajków, a dyskryminacja i przemoc uległy nasileniu. Komisarz oświadczyła również, że powinno się doprowadzić do zintegrowania Romów w krajach, które je przyjmują. Dodała także, iż aktywne wsparcie Komisji Europejskiej, Parlamentu Europejskiego i ONZ, Unia Europejska może wykorzystać do zmiany nastawienia do sprawy romskiej ${ }^{62}$.

W październiku 2010 r. francuskie Ministerstwo ds. Imigracji oświadczyło, iż zamierza utworzyć bazę z odciskami palców Romów, którzy opuścili Francję dobrowolnie, odbierając od rządu zapomogę w wysokości 300 euro. Francja, szukając możliwości zminimalizowania wydatków, ustaliła, iż ograniczeniu ulegnie możliwość wykorzystania zapomogi imigrantów na powrót do państwa francuskiego. Z taką argumentacją nie zgadzały się organizacje ochrony praw człowieka ${ }^{63}$.

W listopadzie 2010 r. unijna komisarz ds. praw podstawowych i sprawiedliwości Viviane Reding uznała, że sytuacja romskiej społeczności jest skandaliczna, nie tylko ze względu na ubóstwo, w jakim mieszkają Romowie, ale również ze względu na brak dostępu do nauki i oświaty dzieci romskich. Za obowiązek uznała rozwiązanie tych kwestii. Ponadto, wystosowała prośbę, aby każde państwo członkowskie przedstawiło „własny program integracji Romów".

We Francji zlikwidowano setki romskich obozów, a od początku roku odesłano ponad 80 tys. Romów do krajów ich pochodzenia ${ }^{64}$.

\section{Unia Europejska a strategia wobec wspólnoty romskiej}

W 2008 i 2010 r. realizowane były projekty włączenia Romów do społeczeństwa, które zakończone zostały bez wypracowania określonego zdania i założeń. Pierwszy projekt, realizowany $w$ Brukseli, stanowił odpowiedź na nieludzkie wydalenia społeczności romskiej z Włoch. Antyimigracyjne nastawienie rządu włoskiego spowodowało podsycanie nienawiści na tle etnicznym, skutkując serią podpaleń i ataków na obozowiska Romów wiosną i latem 2008 r. Obwiniano wówczas tę społeczność o stwarzanie publicznego zagrożenia i wzrost przestępczości. Polityk włoski Umberto Bossi zaapelował, aby Romowie powrócili do swojego kraju. Zdanie to zyskało duże poparcie w wielu krajach unijnych. Nie tylko we Włoszech, partia polityczna Liga Północna (Lega Nord) wprowadza w życie antyimigracyjne idee, ale również w ten sposób działa holenderska Partia Wolności (Partij

61 Na szczycie UE nie będzie konfliktu o Romów?, Polska Agencja Prasowa, http://wiadomosci.gazeta.pl/Wiadomosci/1,80708,8385036, Na_szczycie_UE_nie_bedzie_konfliktu_o_Romow_.html (data pobrania: 14.12 . 2010).

62 Komisarz ONZ o Romach: Dyskryminowana mniejszość, zmuszona do szukania pracy, Polska Agencja Prasowa, http://wiadomosci.gazeta.pl/Wiadomosci/1,80708,8440634, Komisarz_ONZ_O_Romach_Dyskryminowana_mniejszosc_.html (data pobrania: 14.12.2010).

63 P. Markiewicz, Francja zbierze odciski palców wydalanych Romów. Żeby nie wracali, http://wiadomosci. gazeta.pl/Wiadomosci/1,80708,8452993,Francja_zbierze_odciski_palcow_wydalanych_Romow_Zeby.html (data pobrania: 15.12.2010).

64 Reding: Sytuacja Romów w Europie jest skandaliczna, Polska Agencja Prasowa, http://wiadomosci.gazeta. pl/Wiadomosci/1,80708,8654205,Reding_Sytuacja_Romow_w_Europie_jest_skandaliczna.html (data pobrania: 16.12.2010). 
voor de Vrijheid) czy partia Szwedzkich Demokratów (Sverigedemokraterna). Ponadto do tego typu partii, głoszących często ksenofobiczne hasła, zaliczają się: Wolnościowa Partia Austrii (Freiheitliche Partei Österreichs) i Sojusz na rzecz Przyszłości Austrii (Bündnis Zukunft Österreich), Narodowodemokratyczna Partia Niemiec (Nationaldemokratische Partei Deutschlands), belgijski Interes Flamandzki (Vlaams Balang), Słowacka Partia Narodowa (Slovenská Národná Strana), brytyjska Paria Narodowa (British National Party), czy wreszcie francuski Front Narodowy (Front National). Partie te delegują własnych przedstawicieli nie tylko do własnych krajowych parlamentów, ale również do Parlamentu Europejskiego.

Filary ich programów przenoszone są często do unijnych legislatur państw, tworząc zagrożenie dla europejskiej gospodarki. Próba ograniczenia ruchu imigracyjnego nie uzyskuje uzasadnień w makroekonomii, a w przypadku relatywnie wysokiego bezrobocia w Unii Europejskiej (około 10\%) powoduje problemy w braku siły roboczej. Bank Światowy wnosi o otwieranie się na pracowników z innych krajów członkowskich i państw trzecich, a członkowie Unii powinni zabiegać o obcokrajowców i zachęcać ich do dalszego pobytu na terenie ich państwa.

Państwa Unii Europejskiej nie powinny być obojętne na integrację ponad $10 \mathrm{mln}$ Romów, gdyż stanowią oni jedną z najliczniejszych mniejszości etnicznych w krajach europejskich. Istnieje potrzeba doraźnej pomocy przy zapewnianiu godnych warunków życia w obozach romskich, a także konieczność edukacji dzieci romskich, czy próby dokształcania dorosłych - nie tylko pod względem zawodowym, ale i językowym. Dodatkowo, deportacje Romów pozostają sprzeczne z prawem międzynarodowym i unijnym. Działania Francji, poparte przez Włochy czy Czechy, spowodowały odstąpienie Komisji Europejskiej od skargi przeciwko Francji przed Trybunałem Sprawiedliwości 19 października 2010 r. Organ ten uznat, iż gwarancje rządu francuskiego są wystarczające. Francja ponadto zobowiązała się do pełnej ratyfikacji Dyrektywy 2004/3865 o zapewnieniu swobody przepływu osób w 2011 r. ${ }^{66}$

Reakcja Komisji Europejskiej na wydarzenia we Francji nie była wystarczająca. Zgodnie z wyznaczonymi jej zadaniami powinna realnie ocenić sytuację we Francji, biorąc pod uwagę zakaz wydaleń zbiorowych, dyskryminacji ze względu na pochodzenie etniczne i prawa obywateli do przemieszczania się i przebywania na terenie państw członkowskich (kolejno: art. 19, 21 i 45 Karty Praw Podstawowych ${ }^{67}$ ).

Ograniczenie swobody przemieszczania się i pobytu musi być uzasadnione w wypadku oskarżenia o naruszenie porządku publicznego i bezpieczeństwa. Ponadto ograniczenie to powinno opierać się na zasadzie proporcjonalności i indywidualnym zachowaniu jednostki, a nie całej populacji. Podjęcie decyzji o deportacji Romów nie było zgodne z zapisami normatywnymi Dyrektywy, gdyż państwo przyjmujące i wydalające imigrantów powinno uwzględniać długość pobytu imigranta, jego wiek, sytuację ekonomiczną i rodziną, stan zdrowia. Takich decyzji nie usprawiedliwiają nawet względy bezpieczeństwa publicznego ${ }^{68}$.

\section{- • • •}

65 Dyrektywa 2004/38/WE Parlamentu Europejskiego i Rady z dnia 29 kwietnia 2004 r. w sprawie prawa obywateli Unii i członków ich rodzin do swobodnego przemieszczania sie i pobytu na terytorium Państw Członkowskich, zmieniająca rozporządzenie (EWG) nr 1612/68 i uchylająca dyrektywy 64/221/EWG, 68/360/ EWG, 72/194/EWG, 73/148/EWG, 75/34/EWG, 75/35/EWG, 90/364/EWG, 90/365/EWG i 93/96/EWG, Dz. U. L 158/77, http://eur-lex.europa.eu/LexUriServ/LexUriServ.do?uri=DD:05:05:32004L0038:PL:PDF (data pobrania: 1.12.2010).

66 R. Kownacki, Romowie - egzamin (nie)dojrzałości UE, http://wolnemedia.net/spoleczenstwo/romowie\% E2\%80\%93-egzamin-niedojrzalosci-ue/ (data pobrania: 1.12.2010).

67 Karta Praw Podstawowych Unii Europejskiej, Dz. U. Unii Europejskiej, 2007/C 303/01. Patrz: art. 19 - Ochrona w przypadku usunięcia z terytorium państwa, wydalenia lub ekstradycji, art. 21 - Niedyskryminacja, art. 45 - Swoboda przemieszczania się i pobytu.

68 R. Kownacki, op. cit., http://wolnemedia.net/spoleczenstwo/romowie-\%E2\%80\%93-egzamin-niedojrzalosci-ue/ (data pobrania: 1.12.2010). 


\section{Wpływ stereotypów na postrzeganie Romów w Europie}

Przez wiele stuleci ukształtowały się stereotypy postrzegania Romów. Istnieje dwojakie pojmowanie tej społeczności. W pierwszym określa się Romów jako wolnych, nieskrępowanych wędrowców, żyjących bezproblemowo i w zgodzie z naturą; w drugim obrazuje się Romów jako złodziei, oszustów, porywaczy, ludzi naruszających prawo i gnębiących innych. Takie postrzeganie Romów doprowadziło do licznych tragedii, nie tylko w czasie II wojny światowej69. Ostatnie wydarzenia we Francji również pokazują, że negatywny obraz społeczności romskiej jest najbardziej rozpowszechniony wśród krajów europejskich.

Postawa Francji wobec Romów spowodowała zawód wśród wielu działaczy romskich. Romowie przybywali tu w nadziei walki z dyskryminacją w Bułgarii i Rumunii. Zaistniałe wydarzenia we Francji stały się jednak pretekstem dla władz bułgarskich, aby usztywnić ich politykę wobec Romów ${ }^{70}$.

Przepisy unijne broniące Romów, paradoksalnie, stają się bronią przeciwko nim. Minister ds. europejskich Francji Pierre Lellouche określił młodych Romów jako przestępców, pokazując $w$ ten sposób, jak stereotypy oddziałują na postrzeganie zbiorowości przez pryzmat jednostek. Minister zapowiedział, iż w roku 2011 państwo francuskie nie dopuści Bułgarii i Rumunii do strefy Schengen, jeśli państwa te wcześniej nie zadbają o społeczności romskie, które rozprzestrzeniły się w Europie. Cytując Łukasza Wójcika, felietonistę w tygodniku „Przekrój”, można stwierdzić, że „(...) choć Cyganie ładnie grają, to jednak mieszkają w slumsach, są brudni i kradną. Ich Europa nie zamierza bronić"71. Cytat ten wyraźnie pointuje postawę europejskich krajów wobec deportacji Romów z Francji.

\section{PODSUMOWANIE}

Zdarzenia we Francji, jakie rozgrywały się od początku sierpnia 2010 r., były punktem zapalnym w dyskusji nad integracją Romów w Unii Europejskiej. Problem tej grupy etnicznej nie był podnoszony na forum organizacji międzynarodowych i Unii Europejskiej tak wyraźnie, dokładnie i szeroko, jak obecnie. Polityka francuska doprowadziła do wydalenia Romów z kraju pod wpływem jednego incydentu, skutkując licznymi protestami, w których oskarżono Francję o dyskryminowanie tej społeczności. Za pomocą wdrożonych w życie dokumentów doprowadzono do wydalenia z Francji wielu tysięcy Romów, z zastrzeżeniem braku zgody na ich powrót do Francji. Daleko idące oskarżenia instytucji unijnych tak naprawdę nie spowodowały szczególnych zmian w mentalności francuskiego rządu. Obietnice ratyfikowania Dyrektywy o swobodnym przepływie osób na terenie państw unijnych zostaną zrealizowane dopiero w 2011 r., mimo iż dokument ten powstał już w roku 2004.

Postrzeganie Romów w Europie po tych wydarzeniach również nie uległo większym zmianom. Społeczność ta postrzegana jest nadal poprzez pryzmat licznych stereotypów, które nasility się po podniesieniu sprawy ich deportacji z Francji. Na sytuacje obozowisk

69 J. Milewski, Romowie - przyszłość bez uprzedzeń. Informator, Stowarzyszenie Integracja, Suwałki 2009, s. 9.

70 A. Lévy, La France donne un prétexte à la Bulgarie pour durcir sa politique envers les Roms, "Le Monde" 31.08.2010, http://www.lemonde.fr/europe/article/2010/08/31/la-france-donne-un-pretexte-a-la-bulgarie-pourdurcir-sa-politique-envers-les-roms_1404275_3214.html (data pobrania: 3.01.2010).

71 Ł. Wójcik, Prawdziwych Cyganów ma nie być, „Przekrój”, 20 sierpnia 2010, nr 32, s. 16-17. 
romskich zwrócono także uwage w innych krajach europejskich, a wiele partii politycznych o antyimigracyjnym programie stara się wdrażać w życie własne negatywne wnioski, płynące z przyjmowania imigrantów.

Można jednak stwierdzić, że sytuacja Romów w Unii Europejskiej, w wyniku ostatnich wydarzeń, na pewno będzie przez długi czas jednym z głównych tematów na posiedzeniach instytucji nie tylko unijnych, ale i światowych. Każde państwo musi sobie odpowiedzieć na pytanie, czy samo jest zdolne integrować się z Romami i stwarzać im godne warunki do życia w swoich państwach, a także czy obywatele tych państw będą w stanie zaakceptować rosnącą liczbę imigrantów w swoim kraju.

Na podstawie analizy zagadnień praw imigrantów i sytuacji we Francji, a także reakcji Unii Europejskiej na wysiedlenia Romów, można wysunąć następujące wnioski:

1. Unia Europejska stoi na straży przestrzegania praw imigrantów, a jej polityka imigracyjna wiąże się z licznymi zmianami, na jakie narażona jest integracja europejska. Państwa członkowskie, które przyjmują imigrantów, zwracają uwagę nie tylko na rozwój strategii, ale i na powoływanie instytucji, które mogłyby podołać temu narastającemu zjawisku.

2. Polityka Unii Europejskiej wobec imigrantów standaryzowana jest poprzez istnienie traktatów i dyrektyw, regulujących napływ imigrantów, azylantów i uchodźców. Polityka imigracyjna określa normy, na podstawie których państwa europejskie stosują swoje prawo w stosunku do imigrantów.

3. Romowie są grupą etniczną, która funkcjonuje na zasadzie mniejszości narodowej. Uznanie ich za mniejszość jest istotne dla tej społeczności, ponieważ skutkowałoby zrównaniem ich pozycji z innymi społecznościami narodowymi czy etnicznymi w danym państwie przyjmującym.

4. Społeczność romska chroniona jest przez prawo, jednak ze względu na odmienność kulturową ma zróżnicowany status prawny. Dochodzi więc do pojawienia się licznych dylematów powodujących trudności w uznaniu Romów za mniejszość ponadnarodową lub narodową.

5. Relacje pomiędzy państwem francuskim a Unią Europejską po incydencie związanym z deportacją Romów uległy osłabieniu. Padło wiele oskarżeń pod adresem władz francuskich, które spowodowały groźbę postępowania przeciwko Francji przed Trybunatem Sprawiedliwości.

6. Unia Europejska stanowczo potępiła Francję i jej politykę imigracyjną. To jednak nie spowodowało większych zmian w realizacji tej polityki względem społeczności francuskiej.

7. Nagłośnienie sprawy romskiej nie doprowadziło do innego spojrzenia na społecznokulturowy wizerunek Romów. Społeczność romska jest postrzegana przez pryzmat istniejących od dawna stereotypów, które wciąż funkcjonują w świadomości ludzi.

8. Reakcja Unii Europejskiej nie spowodowała gwattownej zmiany w ustawodawstwie francuskim, które broni się przed napływem imigrantów do kraju. Francja ponadto wprowadziła specjalne dokumenty, które mają chronić państwo przed powrotnym napływem mniejszości romskiej na tereny kraju.

9. Dyrektywa o swobodnym przepływie osób na terenie Unii Europejskiej nie została w pełni wdrożona w życie przez państwo francuskie. Zaistniała sytuacja spowodowała jednak, iż ratyfikacja tego dokumentu nastąpi w 2011 r. 


\section{Summary}

The article first presents how immigration policies determine the norms which European Union countries apply in their law towards immigrants. Next the author deals with the Roma as a national minority living in France where it is not yet recognised as equal to other national or ethnic communities. Even though Romany people are protected by law, yet, due to their cultural dissimilarity, their legal status is unstable. Numerous dilemmas arise, thus making it difficult to accept any official recognition of the Roma as a supranational or national minority.

Relations between France and the European Union have deteriorated, since the incident connected with the Roma deportations in 2010. There have been many accusations aimed at the French authorities, and also a threat of bringing proceedings against France before the Court of Justice. The EU strongly condemned France and its immigration policy. This, however, did not change French attitudes towards the Roma. The reaction of the EU did not result in a sudden change in French legislation which aims at preventing an influx of immigrants. In addition, France has introduced special acts to protect the country from a return influx of the Roma minority. The Directive on the free movement of citizens between EU countries has not been fully enforced in France. In the ensuing situation, the ratification of this document will occur in 2011.

Keywords: France, French Roma, deportations, immigration rights 